\title{
What is the potential for reducing national greenhouse gas emissions from crop and livestock production systems?
}

\author{
Eric Audsley ${ }^{1, *}$, Mike Wilkinson ${ }^{2}$ \\ ${ }^{1}$ Centre for Environmental Risks and Futures, School of Applied Sciences, Cranfield University, Bedford, MK43 0AL, UK. \\ ${ }^{2}$ School of Biosciences, University of Nottingham, Sutton Bonington Campus, Loughborough, Leicestershire, LE12 5RD, UK.. \\ ${ }^{*}$ Corresponding author. E-mail: e.audsley@cranfield.ac.uk
}

\begin{abstract}
Agriculture has a devolved commitment to reduce national emissions of greenhouse gases (GHG). Using a systems model-based life-cycle analysis we explored the potential for reducing GHG in systems used to produce twelve crop and seven livestock commodities. With a functional unit of kg of product, differences in GHG between crops reflect differences in yield. Metabolisable energy (ME) or crude protein (CP) could be used, but deriving an economic value of GB£8.6/GJ ME and GB£0.62/kg CP, leads to a relatively consistent $2.6 \mathrm{~kg} \mathrm{CO}_{2} \mathrm{e} / £$ nutrient value. Potential GHG reductions ranged from $2 \%$ (sugar beet) to $15 \%$ (cereals) with agronomic changes, and 4 to $12 \%$ with increased crop yields. The best alternative livestock systems reduced GHG ranging between $7 \%$ (beef from the dairy herd) and $21 \%$ (extensive sheep meat). Half of the options reduced national production and hence increased imports. Overall, improvements in productivity and use of resources are the best options for reducing GHG.
\end{abstract}

Keywords: policy, global warming potential, crops, livestock

\section{Introduction}

Governments have made international commitments to reduce greenhouse gas (GHG) emissions, and the United Kingdom (UK) government has set a target of an $80 \%$ reduction in emissions of GHG by the year 2050 compared to the baseline of 1990 (Office of Public Sector Information, 2011). Each sector of the UK economy is required to reduce GHG, including agriculture (Agricultural Climate Change Task Force, 2010). This paper examines the effects on GHG of implementing theoretically a range of agronomic and livestock husbandry options in typical systems of agricultural crop and livestock production operated on farms in the UK.

Emissions of GHG from agriculture decreased by $20 \%$ in the period 1990 to 2011 according to the National Inventory (DEFRA, 2013), mainly due to reduced amounts of nitrogen applied per ha, which has a significant effect on nitrous oxide emissions, and reductions in the number of dairy cattle and sheep, which affect methane emissions. Improvements in the efficiency of resource use are not currently captured in the National Inventory (MacCarthy et al., 2011). By 2050 the increase in global population will increase the pressure to produce more human-edible food from limited areas of suitable land (Godfray et al., 2010). The ability of ruminant livestock to convert grasslands and forage crops into human-edible food of high nutrient value will continue to make a significant contribution to food output. The sustainable intensification challenge is to produce more total nutrients with reduced total GHG. GHG per unit product focusses attention on more efficient use of agronomic resources in crop production, on increased efficiency of breeding females in livestock production, and on improved efficiency of feed use in all systems of milk and meat production. Technological options may be explored at the individual system level through life-cycle analysis in which the GHG attributed to each component is assessed in a fully authenticated methodology (Williams, 2006). In this way, the impact of variations in management strategies can be quantified theoretically.

Previous research has concentrated on determining the environmental burdens of existing systems of food production (Ledgard et al., 2010; Nemecek et al., 2008; Williams et al., 2006). In this paper we use the Cranfield system-model based life-cycle analysis (LCA) (Williams et al., 2006) to assess theoretically the effects on GHG of implementing a range of technological options in conventional systems of crop and livestock production on farms in northern Europe and United States. The objective is to determine the feasible potential for reducing GHG in each system without reducing the total production of food or changing the national diet. Other studies have considered the scope from making changes to the national diet (Audsley et al., 2009). Organic options are not considered here because they have been explored elsewhere (e.g. Olesen et al., 2006; Weiske and Michel, 2007; Williams et al., 2006) and do not satisfy the requirement not to reduce production from land area. 


\section{Methods}

A range of UK crop and livestock production systems was studied using the Cranfield system-model based agricultural LCA (Williams et al., 2006). All inputs are traced back to primary resources, and all activities supporting the production process such as machinery and fertiliser manufacture, animal feed production and processing are included. Soil is considered to a nominal depth of $0.3 \mathrm{~m}$. Individual GHG emissions of carbon dioxide $\left(\mathrm{CO}_{2}\right)$, methane $\left(\mathrm{CH}_{4}\right)$ and nitrous oxide $\left(\mathrm{N}_{2} \mathrm{O}\right)$ are aggregated and expressed as a global warming potential $\left(\mathrm{GWP}_{100}\right)$ in tonnes $\mathrm{CO}_{2}$ equivalent $\left(\mathrm{CO}_{2} \mathrm{e}\right)$, using a 100-year time frame and the GWP values for gases from the Intergovernmental Panel on Climate Change (IPCC, 2006). For each system, emissions of $\mathrm{N}_{2} \mathrm{O}$ are calculated using the IPCC Tier 1 methodology (IPCC, 2006). Other emissions, such as $\mathrm{CO}_{2}$ and $\mathrm{CH}_{4}$, are calculated systematically by considering each aspect of the system in turn. Emissions associated with the production of imported fertilisers are calculated and included in the analysis. The systems models determine the new long-term steady state for the soil, and as the soil is in steady state, no contribution was assumed for changes in the concentration of soil carbon. GHG were expressed in terms of the functional unit, in this case per $\mathrm{kg}$ of product fresh weight, per MJ of edible energy or per $\mathrm{kg}$ edible protein at the farm gate. The GHG from post farm-gate processing of crops and livestock products were not included in this analysis.

The Cranfield model-based LCA approach includes the impact of changes within the farm system, for example a decrease in fertiliser input reduces crop yield per ha, crop nitrogen content and long-term soil nitrogen. Equally, an increase in the crop yield from plant breeding requires additional fertiliser input. A change in GHG therefore represents the total effect of a change on the farming system. The methods and data inputs to the LCA model have been described in detail for the production of bread wheat, oilseed rape and potatoes in England and Wales by Williams et al. (2010).

Ten UK cropping systems were included in the present study to cover the range of major agricultural food crops (Table 1). Also included were two non-UK feed crops - soya beans and maize grain. Table 1 describes the range of production systems found in the UK in terms of soil texture (clay, loam and sand), soil cultivation practice (ploughing, reduced cultivation or tillage and direct drilling or no-till), rate of straw baling versus incorporation into soil post-harvest, irrigation rates, the average total input of nitrogen $(\mathrm{N})$ per ha and type of nitrogenous fertiliser (Table 1). Manure is a livestock output that offsets the use of fertiliser and is replaced by fertiliser in the analysis of arable cropping. The systems and their emissions were considered as baseline (2005) values for agricultural GHG. The proportion of soil types nationally remained as a fixed constraint.

Table 1. Typical values for soil, cultivation and nitrogen input for crop systems (Williams et al., 2006)

\begin{tabular}{|c|c|c|c|c|c|c|c|c|c|c|c|}
\hline \multirow[t]{2}{*}{ Crop } & \multicolumn{3}{|c|}{ Soil texture (\%) } & \multicolumn{3}{|c|}{ Cultivation (\%) } & \multirow{2}{*}{$\begin{array}{c}\text { Straw } \\
\text { baled } \\
(\%)\end{array}$} & \multirow[t]{2}{*}{$\begin{array}{c}\text { Irrigation } \\
(\%)\end{array}$} & \multirow{2}{*}{$\begin{array}{c}\text { Total } \\
\mathbf{N} \\
(\mathrm{kg} / \mathrm{ha})\end{array}$} & \multicolumn{2}{|c|}{$\begin{array}{c}\text { Type of } \mathbf{N} \text { fertiliser } \\
\text { (\% of total) }\end{array}$} \\
\hline & Clay & Loam & Sand & Plough & $\begin{array}{c}\text { Reduced } \\
\text { tillage }\end{array}$ & No-till & & & & \begin{tabular}{|c|}
$\begin{array}{c}\text { Ammonium } \\
\text { nitrate }\end{array}$ \\
\end{tabular} & Urea \\
\hline Winter bread wheat & 34 & 48 & 18 & 57 & 41 & 2 & 25 & 0 & 219 & 80 & 20 \\
\hline Winter feed wheat & 34 & 48 & 18 & 57 & 41 & 2 & 25 & 0 & 204 & 82 & 18 \\
\hline Winter barley & 22 & 54 & 24 & 57 & 41 & 2 & 85 & 0 & 163 & 82 & 18 \\
\hline Spring barley & 9 & 75 & 16 & 57 & 41 & 2 & 100 & 0 & 123 & 82 & 18 \\
\hline Winter oilseed rape & 43 & 29 & 28 & 50 & 45 & 5 & 0 & 0 & 204 & 69 & 31 \\
\hline Sugar beet & 7 & 82 & 12 & 100 & 0 & 0 & - & 0 & 122 & 96 & 4 \\
\hline Main-crop potatoes & 7 & 82 & 12 & 100 & 0 & 0 & - & 56 & 191 & 96 & 4 \\
\hline Second-early potatoes & 7 & 82 & 12 & 100 & 0 & 0 & - & 48 & 171 & 96 & 4 \\
\hline Field beans & 39 & 33 & 28 & 57 & 43 & 0 & 0 & 0 & 0 & - & - \\
\hline Soya beans & 30 & 28 & 42 & 27 & 53 & 20 & - & 0 & 0 & - & - \\
\hline Maize grain & 30 & 28 & 42 & 30 & 58 & 12 & 0 & 0 & 134 & 90 & 10 \\
\hline Forage maize & 55 & 16 & 29 & 57 & 41 & 2 & - & 0 & 212 & 90 & 10 \\
\hline
\end{tabular}


Table 2. Examples of the livestock systems modelled for each commodity (Williams et al., 2006)

\begin{tabular}{|c|c|c|c|c|c|c|c|c|c|c|}
\hline Sector & Milk & $\begin{array}{l}18 \text { to } 20 \\
\text { month } \\
\text { beef }\end{array}$ & $\begin{array}{c}\text { Cereal } \\
\text { beef }\end{array}$ & $\begin{array}{l}\text { Upland } \\
\text { suckler } \\
\text { beef }\end{array}$ & $\begin{array}{l}\text { Lowland } \\
\text { suckler } \\
\text { beef }\end{array}$ & $\begin{array}{l}\text { Upland } \\
\text { sheep }\end{array}$ & $\begin{array}{c}\text { Lowland } \\
\text { sheep }\end{array}$ & $\begin{array}{c}\text { Pig } \\
\text { meat }\end{array}$ & $\begin{array}{c}\text { Poultry } \\
\text { meat }\end{array}$ & Eggs \\
\hline System & $\begin{array}{l}\text { Autumn } \\
\text { calving }\end{array}$ & $\begin{array}{c}\text { Spring- } \\
\text { born, } \\
\text { dairy-bred }\end{array}$ & $\begin{array}{c}\text { Dairy } \\
\text { cross-bred } \\
\text { bulls }\end{array}$ & $\begin{array}{l}\text { Spring } \\
\text { calving, } \\
\text { grass } \\
\text { finishing }\end{array}$ & $\begin{array}{l}\text { Autumn } \\
\text { calving, } \\
\text { winter } \\
\text { finishing }\end{array}$ & $\begin{array}{l}\text { Cross- } \\
\text { bred hill } \\
\text { ewes }\end{array}$ & $\begin{array}{l}\text { Cross-bred } \\
\text { from upland }\end{array}$ & $\begin{array}{l}\text { Indoor } \\
\text { heavy } \\
\text { bacon }\end{array}$ & Housed & $\begin{array}{c}\text { Housed } \\
\text { layers }\end{array}$ \\
\hline Days housed & 190 & 180 & 399 & 182 & 182 & 0 & 30 & 126 & 42 & 385 \\
\hline Concentrates (kg DM) & 2047 & 960 & 2398 & 579 & 792 & $76^{4}$ & $80^{4}$ & 366 & 4.9 & 52 \\
\hline Forage $^{1}$ (kg DM) & 6792 & 2281 & 120 & 4982 & 4840 & 1018 & 902 & - & - & - \\
\hline Live weight gain (kg/day) & - & 0.90 & 1.23 & 0.88 & 1.03 & 0.17 & 0.19 & 0.56 & 0.06 & - \\
\hline Output (kg/year) & 7850 & 285 & 276 & $232^{3}$ & $225^{3}$ & $60^{5}$ & $63^{5}$ & - & - & 14.8 \\
\hline Slaughter liveweight $(\mathrm{kg})$ & - & 565 & 535 & 565 & 595 & 41 & 44 & 109 & 2.4 & - \\
\hline Age at slaughter (months) & - & 19 & 13 & 20 & 18 & 8 & 7 & 6.3 & 1.5 & - \\
\hline $\begin{array}{l}\text { Feed conversion ratio, } \mathrm{kg} \\
\mathrm{DM} / \mathrm{kg} \text { milk or gain }\end{array}$ & 1.13 & 6.23 & 5.14 & 10.7 & 10.2 & 18.2 & 15.6 & 2.89 & 1.76 & 3.06 \\
\hline $\begin{array}{l}\text { Longevity of breeding } \\
\text { females (years) }\end{array}$ & 3.2 & - & - & 7.0 & 6.5 & 4.2 & 4.5 & 2.5 & - & 1.1 \\
\hline Lambs finished off grass (\%) & & & & & & 35 & 58 & & & \\
\hline Manure as slurry $(\%)$ & 88 & 18 & 18 & 0 & 0 & 0 & 0 & 35 & 0 & $25^{6}$ \\
\hline
\end{tabular}

Livestock production is modelled as a series of component systems within each commodity. There is a wide range in the total period of time the animals are housed. Similarly there is a wide range of systems in intensity of feed inputs, output of animal products and feed conversion ratios (FCRs, defined as $\mathrm{kg}$ feed at constant dry matter (DM) per kg weight gain, milk or eggs at constant DM). Thus the range of modelled milk production systems included autumn and spring calving with different intensities of concentrate feeding. Sheep systems included hill, upland and lowland, pure and cross-bred flocks, with transfers of ewes and lambs between the systems and the option of early lambing. Beef production included suckler and dairy-sourced calves with different levels of finishing based on their levels of grass and concentrates. The main components are shown in Table 2 for a range of example systems. Days housed refers to the total number of days per production cycle that the animals are not outside at pasture. Inputs of concentrate and forage DM refer to the complete production cycle and include both the dam and her offspring. The average live weight gain refers to the offspring and is used to calculate FCR, which includes feed provided to the breeding female where appropriate. Output from the milk system is milk only and does not include meat from the culled cow or from the calf. Surplus calves from the dairy herd are considered in the beef production systems, such as 18 to 20 month beef and cereal beef. In the suckler beef, sheep and pig meat systems the feed inputs and GHG emissions include both the breeding female and the growing offspring.

\section{Results and discussion}

\subsection{Crops}

The GHG from each modelled crop system are shown in Table 3 along with the typical yield and concentration of DM, energy and crude protein of each crop. The range in GHG between crops is considerable, with oilseed rape and sugar beet having the highest and lowest emissions per tonne of crop fresh weight, respectively. With a functional unit of $\mathrm{kg}$ of product, differences between crops in GHG per $\mathrm{kg}$ product reflected differences in yield per ha. Standardising potato and sugar beet yields to $860 \mathrm{~g} \mathrm{DM} / \mathrm{kg}$ fresh weight to make them comparable with the cereal crops produces values of $0.59,0.44$ and $0.20 \mathrm{~kg}$ $\mathrm{CO}_{2} \mathrm{e} / \mathrm{kg}$ for main-crop potatoes, second early potatoes and sugar beet, respectively. Forage maize had the lowest GHG per kg of the cereal crops because, being harvested in its entirety, it had a substantially higher yield per ha than the other crops, though of lower quality. Options to unify crops are to use metabolisable energy (ME) or crude protein (CP) as the functional unit. This provides apparently more consistent GHG per unit, but crops that produce mainly ME (sugar and potatoes) have a very low GHG per unit ME, whereas crops which produce a high concentration of protein have high GHG per unit ME. GHG per kg CP were higher than average for potatoes and sugar beet and lower than average for field and soya beans and forage maize. From the average market prices of all the crops excluding potatoes which is different as it is a crop eaten fresh, it can be estimated by regression that the economic value of a unit of ME is GB£8.6/GJ and CP is $\mathrm{GB} £ 0.62 / \mathrm{kg}$, leading to a relatively consistent $2.6 \mathrm{~kg} \mathrm{CO} \mathrm{CO}_{2} / \mathrm{GB} £$ nutrient value with a smaller range. 
Nitrogen fixing crops are slightly better and high nitrogen crops slightly worse. Note that this simple regression does not incorporate the value of other compositional factors such as low nitrogen in malting spring barley or the amino acid profile of protein crops. The emission of $\mathrm{N} 2 \mathrm{O}$ from nitrogen fixing crops changed in IPCC 2006 from 1996 "because of the lack of evidence of significant emissions arising from the fixation process itself (Rochette and Janzen, 2005)" and is now only related to crop residues.

Table 3. Yield, composition and greenhouse gas emissions (GHG) of different crops and the effect of different functional units

\begin{tabular}{|c|c|c|c|c|c|c|c|c|}
\hline \multirow[t]{2}{*}{ Crop } & \multirow{2}{*}{$\begin{array}{l}\text { Yield } \\
\text { t/ha }\end{array}$} & \multirow{2}{*}{$\begin{array}{l}\mathrm{DM} \\
\mathrm{g} / \mathrm{kg}\end{array}$} & \multirow{2}{*}{$\begin{array}{c}\text { ME } \\
\text { MJ/kg DM }\end{array}$} & \multirow{2}{*}{$\begin{array}{c}\text { CP } \\
\text { g/kg DM }\end{array}$} & \multicolumn{4}{|c|}{ GHG, kg $\mathrm{CO}_{2} \mathrm{e}$ per } \\
\hline & & & & & kg & GJ ME & kg CP & f value \\
\hline Winter bread wheat & 7.7 & 860 & 13.6 & 130 & 0.51 & 0.044 & 4.56 & 3.00 \\
\hline Winter feed wheat & 8.1 & 860 & 13.6 & 116 & 0.46 & 0.039 & 4.61 & 2.83 \\
\hline Winter barley & 6.5 & 860 & 13.2 & 123 & 0.42 & 0.037 & 3.97 & 2.57 \\
\hline Spring barley & 5.7 & 860 & 13.2 & 116 & 0.38 & 0.033 & 3.81 & 2.38 \\
\hline Winter oilseed rape & 3.2 & 930 & 23.1 & 212 & 1.05 & 0.049 & 5.33 & 3.42 \\
\hline Sugar beet & 63.0 & 220 & 13.2 & 68 & 0.04 & 0.015 & 2.87 & 1.25 \\
\hline Main-crop potatoes & 52.0 & 200 & 13.3 & 93 & 0.14 & 0.053 & 7.53 & 2.57 \\
\hline Second-early potatoes & 48.0 & 200 & 13.3 & 93 & 0.10 & 0.038 & 5.38 & 2.90 \\
\hline Field beans & 3.4 & 860 & 13.3 & 298 & 0.51 & 0.045 & 1.99 & 1.98 \\
\hline Soya beans & 2.4 & 860 & 14.5 & 415 & 0.70 & 0.056 & 1.96 & 2.13 \\
\hline Maize grain & 7.2 & 860 & 13.8 & 102 & 0.38 & 0.032 & 4.33 & 2.43 \\
\hline Forage maize (DM) & 11.2 & 280 & 11.0 & 101 & 0.30 & 0.027 & 2.97 & 1.91 \\
\hline
\end{tabular}

$\mathrm{DM}=$ dry matter, $\mathrm{ME}=$ metabolisable energy, $\mathrm{CP}=$ crude protein. Concentrations of $\mathrm{DM}, \mathrm{ME}, \mathrm{CP}$ from Thomas, 2004

Table 4. Predicted yields and greenhouse gas emissions (GHG) for typical crop systems and for technological options to reduce greenhouse gas emissions.

\begin{tabular}{|c|c|c|c|c|c|c|c|c|}
\hline Crop & $\begin{array}{c}\text { Typical } \\
\text { yield }^{1}\end{array}$ & $\begin{array}{c}\text { Yield with } \\
\text { agronomic } \\
\text { options }{ }^{2} \text { to reduce } \\
\text { GHG } \\
\end{array}$ & $\begin{array}{c}\text { Reduction } \\
\text { in yield } \\
(\%)\end{array}$ & $\begin{array}{l}\text { Typical } \\
\text { system }\end{array}$ & No-till & $\begin{array}{c}\text { No-till + no } \\
\text { straw } \\
\text { incorporation }\end{array}$ & $\begin{array}{c}\text { No-till + no } \\
\text { straw } \\
\text { incorporation + } \\
20 \% \text { reduced } N \\
\end{array}$ & $\begin{array}{c}20 \% \\
\text { increase in } \\
\text { crop yield } \\
\text { per ha } \\
\end{array}$ \\
\hline & \multicolumn{3}{|c|}{ (t fresh weight/ha) } & \multicolumn{5}{|c|}{ GHG ( $\mathrm{kg} \mathrm{CO}_{2} \mathrm{e} / \mathrm{kg}$ product fresh weight) } \\
\hline Winter bread wheat & 7.7 & 7.0 & 9 & 0.51 & 0.50 & 0.46 & 0.42 & 0.48 \\
\hline Winter feed wheat & 8.1 & 7.2 & 11 & 0.46 & 0.45 & 0.41 & 0.38 & 0.43 \\
\hline Winter barley & 6.5 & 5.9 & 9 & 0.42 & 0.40 & 0.39 & 0.36 & 0.39 \\
\hline Spring barley & 5.7 & 5.2 & 9 & 0.38 & 0.35 & - & 0.32 & 0.36 \\
\hline Winter oilseed rape & 3.2 & 2.9 & 9 & 1.05 & - & 1.03 & 0.97 & 0.95 \\
\hline Sugar beet & 63.0 & 58.1 & 8 & 0.043 & - & - & 0.04 & 0.04 \\
\hline Main-crop potatoes ${ }^{4}$ & 52.0 & 49.6 & 5 & 0.14 & - & - & 0.13 & 0.13 \\
\hline Second-early potatoes 5 & 48.0 & 46.1 & 4 & 0.10 & - & - & 0.10 & 0.09 \\
\hline Field beans & 3.4 & 3.3 & 4 & 0.51 & 0.46 & - & 0.46 & 0.46 \\
\hline Soya beans & 2.4 & 2.3 & 2 & 0.70 & 0.64 & - & 0.64 & 0.61 \\
\hline Maize grain & 7.2 & 6.7 & 7 & 0.38 & 0.37 & - & 0.33 & 0.36 \\
\hline Forage maize & $11.2^{3}$ & $10.8^{3}$ & 4 & 0.30 & 0.29 & - & 0.26 & 0.29 \\
\hline
\end{tabular}

${ }^{1}$ Systems as described in Table $1 .{ }^{2}$ See text. ${ }^{3}$ t DM/ha. ${ }^{4}$ Cool-stored until May: weighted cooling energy applied. ${ }^{5}$ No storage.

Four agronomic options to reduce GHG were considered as being feasible nationally with current technology: i) a $20 \%$ decrease in applied N; ii) no-till cultivation for all cereals and legumes; iii) zero straw incorporation for all cereals and oilseed rape and iv) irrigate all potatoes. Fresh weight yields for the typical cropping systems and for the options to reduce GHG are shown in Table 4. These options to reduce GHG also reduce crop yields but to a relatively small extent, ranging from $5 \%$ or less for potatoes, field beans, soya beans and forage maize to 7 to $11 \%$ for the other crops. Irrigation of main-crop potatoes was associated with a progressive reduction in GHG, from $0.14 \mathrm{~kg} \mathrm{CO} 2 \mathrm{e} / \mathrm{kg}$ without irrigation to $0.13 \mathrm{~kg} \mathrm{CO} \mathrm{CO}_{2} \mathrm{e} / \mathrm{kg}$ with $100 \%$ irrigation - a $6 \%$ decrease. However as the majority of potato crops are either irrigated or do not need irrigation, the overall potential reduction in GHG is probably only about $1 \%$. Options not considered are chemical nitrification inhibitors and splitting fertiliser applications to reduce the nitrate at risk of being emitted as nitrous oxide if the soil becomes wet.

The model determines the long-term steady state system for all processes. This includes nitrogen from the rotation, nitrate leaching and soil organic matter. Thus a systemic reduction in nitrogen applied, results in a similar reduction in nitrogen in the soil and nitrogen available to the following crop as can be seen in the results of the Rothamsted's Broadbalk experiments. Similarly a long-term change in tillage or residue 
management changes the steady state carbon content of the soil, mostly over 20 years (IPCC 2006) but we analyse the emissions from the steady state values not the change.

No-till is associated with a reduction in GHG, mainly as a result of lower primary energy use. An exception is oilseed rape, where the change from 5\% no-till to $100 \%$ no-till is associated with an increase in GHG of $0.04 \mathrm{~kg} \mathrm{CO}_{2} \mathrm{e} / \mathrm{kg}$ because the relatively high yield penalty (13\%) outweighs the savings in primary energy. The restrictions of applying the IPCC Tier 1 emission factors mean that the model assumes there are no changes in soil $\mathrm{N}_{2} \mathrm{O}$ emissions for different cultivation techniques. However there may be an increase in $\mathrm{N}_{2} \mathrm{O}$ compared to the typical system because of increased soil anaerobic conditions (Robertson et al., 2000).

The main source of GHG due to incorporating straw into soil is $\mathrm{N}_{2} \mathrm{O}$ emission from soil during the winter (IPCC, 2006). Incorporating (or not incorporating) straw continues indefinitely, so the soil is in steady state and there is no contribution from the change in the soil organic matter. In the transition period, soil organic matter would be reduced by not incorporating (Smith et al., 1996), releasing $\mathrm{CO}_{2}$, which the benefit of reduced $\mathrm{N}_{2} \mathrm{O}$ would take some years to counteract, and vice-versa. The magnitude of the effect of a change away from straw incorporation depends on the proportion of straw incorporated for each crop.

A reduction in the total quantity of $\mathrm{N}$ input is associated with decreased primary energy use and reduced emissions of $\mathrm{N}_{2} \mathrm{O}$ since under the Tier 1 IPCC methodology the emission factor for $\mathrm{N}_{2} \mathrm{O}$ is a fixed percentage (1\%) of total N applied (IPCC, 2006). Progressive decreases in total $\mathrm{N}$ input not only reduce crop yields and soil nitrate concentrations but also reduce emissions of ammonia. An effect of reducing total $\mathrm{N}$ input is that the concentration of $\mathrm{N}$ in the crop is also reduced. This reduces the likelihood of bread wheat grain being of a suitable quality for bread-making. A switch to a variety with a higher inherent protein content might be feasible, but these varieties are also lower-yielding (HGCA, 2011). Reduced N content is unlikely to be consequential in the case of potatoes and sugar beet as it is not a quality criterion for these crops. Reductions in total $\mathrm{N}$ input were analysed to determine an appropriate level which might reduce GHG by more than crop yields to give a net environmental benefit per unit of crop produced. An average reduction of $20 \%$ in total N input produced a net GHG benefit for all crops and was therefore considered to be the most appropriate option. Kindred et al. (2008) found a similar optimal reduction in fertiliser $\mathrm{N}$ input to UK wheat of $43 \mathrm{~kg} / \mathrm{ha}$ (a $22.5 \%$ reduction) to minimise GHG, after accounting for land-use change to maintain grain output.

Where all three agronomic options were appropriate to the crop, reduced $\mathrm{N}$ had the greatest effect on GHG. The combined effect of the options on the percentage reduction in GHG was lowest for sugar beet (2\%) and highest for the cereal crops (average 15\% reduction). The percentage reduction in GHG was similar for the two potato crops (3\%), and was also similar for the grain legumes (9\%).

The yield of the major grain crops has increased steadily over the years, and there is undoubtedly scope for them to be increased further - for example through improved plant breeding and crop health (see review by Godfray et al., 2010). Table 4 shows GHG per kg product were reduced by a theoretical increase in yield of $20 \%$. The system models increase the fertiliser $\mathrm{N}$ input to the crops to balance the increased $\mathrm{N}$ off-take. For crops other than cereals and forage maize the effect on GHG of a $20 \%$ increase in yield alone was greater than the combined effects of the agronomic options, ranging from a 5\% reduction for main-crop potatoes to a $14 \%$ reduction for soya beans.

\subsection{Livestock}

GHG from livestock systems are average values for each sector - milk, dairy beef, suckler beef, sheep meat, pig meat, poultry meat and eggs (Table 5). Milk production has apparently lower GHG per $\mathrm{kg}$ product, but this is due to the fact that milk is largely water. Differences between semi-intensive (18-20 month) and intensive (cereal) dairy beef, between upland and lowland suckler beef, and between upland and lowland sheep were relatively small in terms of GHG/kg of product at the farm gate, in agreement with farmbased studies in the UK (EBLEX, 2010; QMS, 2011). On a DM basis, primary energy use for milk production is similar to that of poultry production, reflecting the energetic efficiency of converting feed into milk rather than live weight. However, GHG is always higher for ruminants due to the methane emitted during rumination. GHG per kg product were also substantially higher for suckled beef and sheep meat production than for beef produced from calves born in the dairy herd (dairy beef) and non-ruminant systems, reflecting the relatively high overhead feed cost of the breeding female (Table 3). Differences in GHG 
between the meat production systems per unit of edible energy and edible protein were similar to those per $\mathrm{kg}$ fresh product, with suckler beef having the highest, and poultry meat the lowest GHG per MJ of edible energy and per kg edible protein.

The best alternative system in terms of reduced GHG compared to the combined typical systems was identified for each livestock sector using the Cranfield model (Table 5). Alternative systems were defined using the model with the most extreme feasible improvement in each factor in order to estimate the maximum potential for reducing GHG. By increasing fertility (number of successful conceptions per female inseminated), fecundity (number of offspring per breeding female in sheep) and longevity (number of years in production), the overhead costs of rearing herd and flock replacements are reduced. However, using the system model identified a problem with the simplistic statements "increase annual milk yield" and "increase daily growth rate". This can mean three very different things:

1) Both can be achieved by having a larger animal. Thus a dairy cow which is $10 \%$ larger will be expected to require about $7.5 \%$ more food for maintenance, give $10 \%$ more milk and require almost $10 \%$ more food because of that milk and hence will have much the same GHG per kg milk.

2) The same size of animal giving more milk, which requires more food. This reduces the maintenance element of the GHG, but it is only a small reduction.

3) The same size of animal giving more milk but eating no more food. This reduced GHG substantially.

Increased annual milk output should also not be confused with yield per lactation, which can be increased by having a longer calving interval. Similarly, improving FCR makes more efficient use of resources. Increased daily live weight gain and lower age at slaughter may save resources, but an animal that is simply larger may achieve a greater daily live weight gain but consume pro-rata more feed with no improvement in its FCR. The analysis presented here does not distinguish between methods to improve FCR. In some cases, diet re-formulations may improve FCR but increase the environmental burdens of feed production and not reduce GHG.

Table 5. Estimated GHG for typical and alternative livestock systems

\begin{tabular}{|c|c|c|c|c|c|c|}
\hline \multirow[b]{2}{*}{ Sector } & \multicolumn{3}{|c|}{$\begin{array}{l}\text { Typical system } \\
\mathrm{kg} \mathrm{CO}_{2} \mathrm{e} \text { per }\end{array}$} & \multirow[b]{2}{*}{ Best alternative system } & \multicolumn{2}{|c|}{$\begin{array}{c}\text { GHG from } \\
\text { alternative system } \\
\mathrm{kg} \mathrm{CO} 2 \mathrm{e} \mathrm{per} \\
\end{array}$} \\
\hline & $\begin{array}{c}\mathbf{k g} \\
\text { product }^{1}\end{array}$ & $\begin{array}{c}\text { MJ edible } \\
\text { energy }\end{array}$ & $\begin{array}{l}\text { kg edible } \\
\text { protein }\end{array}$ & & $\begin{array}{c}\text { kg } \\
\text { product }^{1}\end{array}$ & $\begin{array}{c}\% \\
\text { reduction }\end{array}$ \\
\hline Milk & 1.0 & 0.4 & 30.6 & $\begin{array}{l}\text { Autumn-calving cows, housed } 190 \text { days/year. } 8000 \text { litres per year, } \\
7 \text { lactations per cow. } 15 \% \text { crude protein housed diet based on } \\
\text { maize silage. }\end{array}$ & 0.89 & 12 \\
\hline Dairy beef & 8.5 & 1.0 & 49.5 & Lower protein and lower forage diet, housed throughout lifetime. & 7.95 & 7 \\
\hline $\begin{array}{l}\text { Suckler } \\
\text { beef }\end{array}$ & 15.9 & 1.9 & 90.0 & $\begin{array}{l}\text { Extended grazing. Spring calving. High genetic merit cow for } \\
\text { fertility and calf growth. }\end{array}$ & 14.1 & 12 \\
\hline Sheep meat & 14.6 & 1.6 & 69.3 & $\begin{array}{l}\text { Extensive. Ewes of high genetic merit for fecundity and longevity. } \\
\text { No housing. }\end{array}$ & 11.5 & 21 \\
\hline Pig meat & 4.0 & 0.7 & 19.7 & $\begin{array}{l}\text { High fertility and piglet growth. Sows and weaners outdoors. } \\
\text { Finishing indoors on slurry system, applied slurry immediately } \\
\text { incorporated into land. }\end{array}$ & 3.49 & 14 \\
\hline $\begin{array}{l}\text { Poultry } \\
\text { meat }\end{array}$ & 2.7 & 0.3 & 14.2 & $\begin{array}{l}\text { Housed. Immediate incorporation of applied manure into land. } \\
\text { FCR as for top } 10 \% \text { of sector. }\end{array}$ & 2.54 & 7 \\
\hline Eggs & 3.0 & 0.5 & 23.2 & $\begin{array}{l}\text { Housed, slurry, under-floor drying of manure, Immediate } \\
\text { incorporation of applied manure into land. FCR as for top } 10 \% \text { of } \\
\text { sector. }\end{array}$ & 2.57 & 13 \\
\hline
\end{tabular}

FCR=Feed Conversion Ratio ${ }^{1}$ Whole milk and eggs, bone-in carcase weight

Gill et al. (2009) reviewed the role of livestock in mitigating agricultural GHG and concluded that improving efficiency of animal nutrition and management of grazed pastures and manure, together with improved efficiency of production through better animal breeding, health interventions and improved fertility, can all potentially decrease GHG per unit of product. In the current study the main factors identified in the model which reduced GHG were output per breeding female (ruminants), FCR and manure management. The potential reductions in GHG range from $7 \%$ for dairy beef and poultry meat to $21 \%$ for sheep meat. The major factors affecting GHG per unit of milk are annual yield per cow, longevity and reduced protein diets. The best alternative milk production system is longevity at 7 lactations per cow rather the current average of 3.2 lactations per cow. The best alternative beef production system uses calves from the dairy herd. The use of sexed semen in dairy herds was examined as a possible option. There was little 
effect on the total number of male and female dairy-bred calves available for beef. The scope for reducing GHG from suckler beef systems is limited by the relatively low output of beef per breeding female per year. However, suckler beef herds make use of land producing low-quality pasture, whose soils are too poor to produce arable crops or the high-quality pasture necessary for milk production (Wilkinson, 2011). Overall FCR of ruminant meat production is substantially poorer than that of the monogastric livestock systems (Table 2). The best alternative suckler system comprises spring-calving suckler cows with extended grazing (i.e. minimal housing) to minimise $\mathrm{N}_{2} \mathrm{O}$ emissions from farmyard manure. The best alternative pig production system comprised sows of high genetic merit for fertility and piglet growth, sows and weaners kept outdoors and indoor finishing with manure as slurry. Greater emissions of $\mathrm{N}_{2} \mathrm{O}$ from the outdoor system are more than offset by the reduction in methane which would otherwise be produced from stored manure or slurry. There is, however, an increased risk of nitrate leaching from the outdoor system compared to fully-housed systems. Poultry production is relatively efficient compared to other livestock sectors, and there is relatively little scope for reductions in GHG. The best alternative system of poultry meat production is indoor-housed as is the case with egg production, which may conflict with modern welfare preferences.

Criteria other than GHG need to be taken into account in determining the best options. Half of the cropping options reduce national production of the commodities. Apart from potential issues of human food security, increased imports of food into the UK are likely to affect global agriculture and carry the risk of increased deforestation with consequent severe increases in GHG emissions. No-till increases pesticide use (Williams, 2006). Whilst decreasing nitrogen fertiliser reduces nitrate leaching (Smith et al., 1996), increased yields from crop breeding have a negligible effect on nitrate leaching even though the model requires that nitrogen input be increased pro-rata with yield in order to give the same level of nitrogen-input intensity. Overall the results indicate that improvements in productivity and use of resources are the best options for reducing GHG per unit of product without other deleterious effects.

\section{Conclusions}

Of the options found to reduce crop GHG, reduced fertiliser $\mathrm{N}$ and increased yield per hectare were the most feasible, giving reductions in GHG of between 5\% and $15 \%$ compared to typical systems. Options found to reduce GHG in livestock production were increased fertility, fecundity and longevity of breeding females, increased annual milk yield per dairy cow, improved FCR in meat animals and immediate incorporation of slurry following its application to land giving reductions of between 7 and $21 \%$. However the best that is likely to be achieved overall is around a $10 \%$ improvement, in agreement with the aspiration of the UK Greenhouse Gas Action Plan (Agricultural Climate Change Task Force, 2010). There is scope to reduce GHG in all sectors of agricultural production by applying existing knowledge.

\section{Acknowledgement}

The research on which this paper is based was funded by the Department for Environment, Food and Rural Affairs (DEFRA, projects IS0205, AC0208 and IS0222), whose support is gratefully acknowledged.

\section{References}

AFRC, 1984 The Nutrient Requirements of Ruminant Livestock - Protein. CAB, Farnham Royal, UK. Agricultural Climate Change Task Force, 2010. Agriculture Industry GHG Action Plan: Framework for Action. www.nfuonline.com/Our-work/Environment/.../GHGAP-10Feb2010/ Accessed 17 February 2012.

Audsley, E., Brander, M., Chatterton, J., Murphy-Bokern, D., Webster, C., Williams, A., 2009. How low can we go? An assessment of greenhouse gas emissions from the UK food system and the scope for reduction by 2050 . How low can we go? WWF- UK.

DEFRA, 2013. Agricultural Statistics and Climate Change, $4^{\text {th }}$ Edition, July 2013. Available online at: http://www.defra.gov.uk/statistics/foodfarm/enviro/climate/

English Beef and Lamb Executive (EBLEX), 2010. Testing the Water. The English Beef and Sheep Production Environmental Roadmap - Phase 2. EBLEX, Kenilworth, UK 47 p.

Flachowsky, G, Lebzien, P. 2006 Possibilities for reduction of nitrogen $(\mathrm{N})$ excretion from ruminants and the need for further research. Landbauforschung Völkenrode, 56: 19-30. 
Garnsworthy, P. C., 2004. The environmental impact of fertility in dairy cows: A modelling approach to predict methane and ammonia emissions. Animal Feed Science and Technology 112: 211-223.

Garnsworthy, P.C. 2012. Sustainable intensive farming systems. In: Casasus I, Rogosoc J, Rosati A, Stokovic I and Gabina D, eds., Animal Farming and Environmental Interactions in The Mediterranean Region. Wageningen Academic Publishers. 139-143.

Gill, M., Smith, P., Wilkinson, J.M. 2009. Mitigating climate change: the role of domestic livestock. Animal, 4: 323-333.

Godfray, H.C.J., Beddington, J.R., Crute, I.R., Haddad, L., Lawrence, D., Muir, J.F., Pretty, J., Robinson, S., Thomas, S, Toulmin, C., 2010. Food security: The challenge of feeding 9 billion people. Science 327: 812-818.

Home-Grown Cereals Authority (HGCA), 2011. HGCA Recommended List Winter Wheat 2012/13. HGCA, Kenilworth, UK.

Intergovernmental Panel on Climate Change (IPCC), 2006. IPCC Guidelines for National Greenhouse Gas Inventories. Volume 4. Agriculture, Forestry and Other Land Use. Task Force on National Greenhouse Gas Inventories.

Kindred, D., Berry, P., Burch, O., Sylvester-Bradley, R. 2008. Effects of nitrogen fertiliser use on green house gas emissions and land use change. In: Halford, N., Jones, H.D., Lawlor, D. (eds )Aspects of Applied Biology 88, Effects of Climate Change on Plants: Implications for Agriculture. Association of Applied Biologists, Warwick, UK. p. 1-4.

Ledgard, S.F., Lieffering, M., McDevitt, J., Boyes, M., Kemp, R., 2010. A Greenhouse Gas Footprint Study for Exported New Zealand Lamb. Report prepared for the Meat Industry Association, Balance AgriNutrients, Landcorp and MAF. March 2010

MacCarthy, J., Thomas, J., Choudrie, S., Thistlethwaite, G., Passant, N, Murells, T.P., Watterson, J.D., Cardenas, L., Thomson, A., 2011. UK Greenhouse Gas Inventory, 1990-2009. AEA Technology plc, Harwell, UK.

Nemecek, T., Gaillard, G., 2008. Life Cycle Assessment in the Agri-Food Sector. Proc. of the 6th Int. Conf. on LCA in the Agri-Food Sector, Zurich, November 12-14, 2008. Agroscope Reckenholz-Tänikon Research Station ART

Office of Public Sector Information, 2011. Climate Change Act 2008. http://www.legislation.gov.uk/ukpga/2008/27/contents Accessed 4 January 2012.

Olesen, J.E., Schelde, K., Weiske, A., Weisberg, M.R., Asman, W.A.H., Drurhuus, J., 2006. Modelling greenhouse gas emissions from European conventional and organic dairy farms. Agriculture Ecosystems and Environment, 112: 207-220.

Quality Meat Scotland (QMS), 2011. Estimating Greenhouse Gas Emissions from Scottish Livestock Enterprises. QMS, Ingelston, Scotland. $17 \mathrm{p}$.

Reynolds, C.K., Crompton, L. A., Mills, J.A.N., Humphries, D.J., Kirton, P., Relling, A.E., Misselbrook, T.H., Chadwick, D.R., Givens, D.I. 2010. Effects of diet protein level and forage source on energy and nitrogen balance and methane and nitrogen excretion in lactating dairy cows. In Corvetto, G.M. (ed). Proceedings of the $3^{\text {rd }}$ International Syposium on Energy and Protein Metabolism, EAAP Publication No. 127, Wageningen Academic Publishers, The Netherlands, pp 463-464.

Robertson, G.P., Paul, E.A., Harwood, R.R., 2000. Greenhouse Gases in Intensive Agriculture: Contributions of Individual Gases to the Radiative Forcing of the Atmosphere. Science 289, 1922-192

Rochette, P. and Janzen, H.H. (2005). Towards a revised coefficient for estimating N2O emissions from legumes. Nutr. Cycl. Agroecosyst., 73, 171-179.

Smith, J.U., Bradbury, N.J., Addiscott, T.M. 1996. Sundial: a PC-Based System for Simulating Nitrogen Dynamics in Arable Land. Agronomy Journal, 88, 38-43.

Thomas, C. (Ed.), 2004. Feed into Milk. A New Applied Feeding System for Dairy Cows. Feed Database. Nottingham University Press, Nottingham, UK. 68 p.

Weiske, A., Michel, J., 2007. Greenhouse gas emissions and mitigation costs of selected mitigation measures in agricultural production. MEACAP WP3 D15a. http://www.ieep.eu/assets/589/ wp3_d15a_ghg_and_mitigation.pdf\%20Accessed\%2004\%20January\%202012

Wilkinson, J.M., 2011. Redefining efficiency of feed use by livestock. Animal 5: 1014-1022.

Williams, A.G., Audsley, E., Sandars, D.L., 2006. Determining the environmental burdens and resource use in the production of agricultural and horticultural commodities. Main Report. Defra Research Project IS0205. Cranfield University, Bedford, UK. 97p. http://randd.defra.gov.uk/ 
Williams, A.G., Audsley, E., Sandars, D.L., 2010. Environmental burdens of producing bread wheat, oilseed rape and potatoes in England and Wales using simulation and system modelling. International Journal of Life Cycle Assessment 15: 855-868. 